\title{
Modernity Retranslated: Nationalism as a Tool of Culture in a Complex Polysystem
}

\author{
Ayşe Betül SAYIN*
}

The purpose of this paper is to problematize comparative modelling of descriptive retranslation research with respect to nationalism in a polysystem. In this light, it starts by questioning a tool of analysis, i.e., 'non-(re)translation,' that studies resort to as a nominal concept yet underneath imply opposing views of philosophy of language. This foregrounding of the concept requires meticulous contextualization in order to deconstruct the systemic stratification of a specific period. The corpus comprises four translations (plus a reprint) of the prominent Ottoman and Turkish historian Uriel Heyd's Foundations of Turkish Nationalism: The Life and Teachings of Ziya Gökalp, originally published in 1954. Given that the initial translation in the corpus appeared shortly before the 1980 coup d'état in Turkey and the most recent translation was published soon after the induction of the democratic initiative process in 2009 , the descriptive study analyzes the translation norms and strategies of each translated work and looks for an answer as to whether the initial norm corresponds to translation policy and how it governs the textual-linguistic norms in turn. In addition, the empirical analysis serves the purpose of theorizing the workings of national category in a complex polysystem. Thus, instrumentalization of a 'national' symbol can elucidate the manner in which ideational labor is deployed to produce energy in heterogeneity. Following the theoretical and empirical analyses, questions with regards to future comparative analysis and modelling are raised.

Keywords: retranslation; polysystem studies; nationalism; complexity; comparative modelling

\section{Introduction}

The retranslation scholarship has witnessed an unprecedented accumulation of research in recent years. As a research topic, it accrues in abundance in terms of methodological perspectives. The 'premiering' argument for an empirical hypothesis is predominantly attributed to Antoine Berman's article titled "La retraduction comme espace de la traduction" (Retranslation as a translation space) published in 1990. Though recent research does not necessarily share Berman's method of analysis and answer to his call for translation criticism, the literature is conspicuously inattentive to the major paradigms of translation studies. Leaving

\footnotetext{
* PhDc at Istanbul 29 Mayıs University.

E-mail: ayse.b.sayin@gmail.com; ORCID ID: https://orcid.org/0000-0002-8251-697X.

(Received 4 March 2020; accepted 12 June 2020)
} 
the unilinear positioning of time, space, and hence language in Berman's retranslation hypothesis based on German idealism to another study, ${ }^{1}$ the present one attempts to fill a gap in retranslation research that Kaisa Koskinen and Outi Paloposki (2019) underscore by "macro level approaches" (23). For this purpose, a 'multi-pronged approach' is surely necessary; however, as this study indicates, it is already available. Recalling Hans J. Vermeer's point of stance with reference to David Hull's "The Naked Meme," I suggest that researchers of retranslation better consider the fact that "most conceptual evolution does not occur via innovations but by means of the recombinations of the same old ideas, not by novel ideas but by novel combinations of familiar ideas" (Hull 1982, 307 quoted in Vermeer 1998, 41).

Thus, this article is an experiment on how to combine a familiar concept of longestablished and disputed social science, i.e., nationalism, with research on retranslation tested on a 'new, targeted data set' on the very foundation of a retranslation culture. Analysis on comparative nationalisms across time and in various geographies-specifically relatively young nation states in the post-imperial world - has proven to be a topic of much consideration. Among the subjects of such analysis, Turkish state definitely has a place of its own. In this respect, the retranslated works within the targeted data set of the present study will be efficacious for an enquiry into the translations of nationalism in a very specific period. The initial translation was published just before coup d'état that took place on 12 September 1980 only to encounter dissent in a new one appearing at a short interval. Therefore, this paper delves into a detailed descriptive and explanatory analysis asking who sings the nation-state ${ }^{2}$ in Uriel Heyd's narrative on the father of modern sociology in Turkey and one of the principal theorizers on Turkish nationalism, Ziya Gökalp, as well as the many songs of representations in the Turkish target system first heard in 1979 and sustained till today. The corpus comprises translations of Heyd's Foundations of Turkish Nationalism: The Life and Teachings of Ziya Gökalp ${ }^{3}$ in five versions published in 1979, 1980, 2001, 2002, and 2010, respectively. This data set also provides empirical evidence for questioning aging of language as raison d'être of retranslation, which the study by Koskinen and Paloposki (2019) calls "self-fulfilling prophesy

\footnotetext{
${ }^{1}$ The historical construction of a theory of translation from the 'German' roots of comparative literature and the totalitarian nature of such theorizing require specific research into how complexity thinking is reflected in systemic approaches to translation studies. See Sayın 2020.

${ }^{2}$ The canonized status of Ziya Gökalp's infamous Türkçülüğ̈̈n Esasları (The principles of Turkism) recalls questions that Judith Butler (2007) voices in her criticism of Hannah Arendt's works, which provoke discussion, such as "who sings the national anthem?" (27) and "to whom does this anthem belong?" (58).

${ }^{3}$ From now on Foundations.
} 
of aging" (32).

The above-mentioned study asserts that a methodological failure is found in addressing the function of a particular translated work to be published in reprints and revisions. This article stresses that the constant amusement with the problem of aging might have obscured a more significant aspect of identifying rather larger epochs in retranslation scholarship. Yet, first a clarification is due particularly in light of terms used in studies on retranslation and the epistemology behind them, since a remarkable similarity is observed in Berman's (1990) "nontraduction" (non-translation) (5) and Koskinen and Paloposki's (2019) “non-retranslation” (31). Berman (1990) attributes "non-translation" to failure of a translated work and hence quite lucidly denies existence of a translation, when he suggests: "Toute traduction est défaillante, c'est- à-dire entropique, quels que soient ses principes. Ce qui veut dire: toute traduction est marquée par de la "non-traduction"” (5; Any translation is faulty, i.e., entropic, no matter what the principles are. It means that every translation is marked by a "non-translation"; my translation). On the other hand, Koskinen and Paloposki (2019) describe non-retranslations as special cases of non-aging and define the term as "works that remain relevant and read but do not get retranslated or revised" (31-32). The very first translation of Heyd's Foundations provides a remarkable case for this methodological drawback only proper contextualization can ameliorate. In this respect, the extraordinary period of political and social transformation during which the translations appeared should be stressed. Nurdan Gürbilek, a prominent literary critic, distinguishes between two different cultural strategies that interconnect with each other as she expresses:

For throughout the 1980s, neither strategy ever took the other's place; it was rather that they came into being each calling upon the other, each dependent upon the other for its effectiveness, each owing its legitimacy to the other. ... What the first represses, the second provokes, transforms and includes. What the second provokes, the first represses. $(2011,7)$

The first one of these seemingly 'contradictory' characteristics is the repression, state violence, and suppression of social opposition by force, which eradicated the radical left movement of the 1970s. However, the second characteristic of the period leaving an imprint on the social strata, in Gürbilek's words, reflected "a more liberal, more comprehensive, more inclusive strategy of power" $(2011,6)$. The "ostracized contents" (84) of the modernizing project of Kemalism such as 'the rural' and the religion returned in the shadow of victimhood. 
The new cultural climate was manifest with maneuvers "aiming to encircle by speech rather than in silence, to transform rather than prohibit, internalize rather than destroy, tame rather than suppress" (6). Thus, this transformation from an exhausted state 'ideal' to the free market opened the way for an acknowledgment of a 'belatedly modern' society that was inevitably entangled in a double-bind, as Gürbilek puts it:

[A] double bind ... a link of double engagement which has always produced antithetical emotions in the cultural sphere, of an abandon and summons to return to the self, an enthralment and fear of losing the self, admiration of the foreign and xenophobia forced to live side by side in a single soul, a sense of inadequacy and grandiosity, victimhood and defiance, and finally a political-cultural milieu that persists in inciting those feelings. $(2011,15)$

On the face of modernity, most critics seem to agree that in such a cultural climate it was pointless to search for an intuitive discovery of an untouched essence anymore (see Tanpınar 2013; Mardin 1974). Therefore, the inability to determine the nature of the self created a malevolent energy and a struggle for power within a dichotomous structure. What the great Turkish modernist Vüsat O. Bener labels as "obstinate inauthenticity” (Gürbilek 2011, 159) sets the stage for a polysystem perceived to frame an utter heterogeneity and complexity. Not surprisingly, according to Gürbilek, this perplexing atmosphere gradually gave way to another explosion from the 1990s onwards: the crusade for 'Turkishness.' This particular emphasis on 'the nation' shapes the context in which the retranslations that will be descriptively analyzed in the present study came into being. In light of this, this study looks for an answer to whether the periodization of a specific non-retranslation may be pointing to a marked pattern of a retranslation epoch, given that the "sense of injury, introversion, wounded pride, anxiety, rage and resentment" attributed to the workings of the nationalistic discourse was felt most deeply (14).

On account of the illuminating arguments made above, the present study will progress with several questions. Can retranslations work as a tool for comparing systemic entities across different target (poly-)systems? What can retranslations tell us in view of the maintenance of systems? Furthermore, can we challenge the established stages of nationalistic politics (cf. revival of epic in Frantz Fanon's The Wretched of the Earth) by comparing different systems such as German, Turkish, and Israeli on the basis of retranslations? Can studies on retranslation alter the way politics of nationalism are historically constructed on the macro level? 


\section{The 'Nation' in the Polysystem}

In an attempt to answer the aforementioned questions, this study systemically analyzes the function literature has in a certain designated network comprising, without doubt, culture, power, and nation. Thus, for the purposes of studying literature, especially the canonized source texts and their retranslations academically and "not as brokers," the theoretical framework will focus on what polysystems can reveal about one of the most stimulative collective entities such as 'nation' (Even-Zohar 2002b, 82).

For understanding "the function of literature in the making of many nations" $(1996,40)$, Itamar Even-Zohar posits literature as "the indispensabilia of power," something which is equivalent to "possessing riches appropriate for a powerful ruler" (45). Interpreting literature from a socio-semiotic perspective, Even-Zohar states that besides its value as goods, hence a symbol of power, literature serves as "an ever-present factor of socio-cultural cohesion in our society" (42; emphasis mine). The term 'cohesion' in this respect refers to several underlying notions, i.e., a larger systemic entity, smaller entities, or, in other words, constituents recognized to be heterogeneous, and competition accompanied by some sort of negotiation between these smaller entities or 'structures.' How this cohesion is attained is directly related to what is meant by literature, as Even-Zohar expresses:

Here "literature" signifies a whole aggregate of activities, only part of which are "texts to be read," or "to be listened to," or even "to be understood." In short, these activities include production and consumption, a market and negotiational relations between norms. $(1996,44)$

This relationship between different agents of a yet single market would eventually aspire persons in distinct semio-cultural systems to possess an 'authentic' "repertoire of commodities and procedures" (Even-Zohar 1996, 45). Along with this line of thinking, an entity's self-positioning itself in competition with more powerful groups possessing cultural commodities unavailable to it makes sense considering market provides ground for channels of exchange and negotiation (48-49). Yet, moving onto the topic of inter-systemic relationships, the role literature plays in view of the formation of, at least, a single roughly-differentiated group needs to be addressed.

Therefore, we must return to our initial question: How does literature construct or mold heterogeneous entities as the unitary concept of nation denotes? Given the canonized nature of 
the book the present study will analyze, any translation of life and works of Gökalp into English magnifies the fractures in the internalization of nationalism - though much criticized as a somewhat incoherent combination of Émile Durkheim's sociology and German tradition of nation-building (see Edwards 1951) — and how it compares to such other political ideologies on a larger scale. In that light, on the lately-invented nations of Europe, Even-Zohar notes:

Texts, produced together with a new or a re-standardized language, functioned in all of these cases as a major vehicle of unification for people who would not necessarily consider themselves as "belonging to" a certain entity. $(1996,51)$

The work cultural entrepreneurs undertake in the process of nation-making can be defined as bringing an order to a 'repertoire' of texts and persons-in-the-culture "which in principle could be rendered instrumental in justifying what their cause" (Even-Zohar 1996, 52). The ultimate purpose of guiding the development of a national entity is achieving a sense of establishment, in our case, establishing a national language and a national literature that is "equivalent to the act of acquiring self-identifying, and self-edifying commodities" (53). Yet, when such an act of cultural translation in the widest sense of the concept ${ }^{4}$ is put to the test of acceptability and adequacy, the functioning of the "European model [of nation-making] for non-European cultures" (55) requires other aspects of polysystem and complexity to be recognized. This complexity is manifested first and foremost in the selection criteria for the book in the present case study. Thus, Even-Zohar's initial theorizing on "packaging of a language with a 'nation,' whose existence was substantiated, justified, motivated, and defended by ... the wealth of narratives about its alleged common "past"" requires in-depth analyses because clearly there is not solely one model as to how this package will utilize "the glory of the linguistic tool developed at some time by some of its members" (54). In the present case, how the metanarrative by a 'foreign' name is appropriated into the 'domestic' polysystem is a question waiting for an answer, because the linguistic tool is not apparently developed by a conceivably inner member of the national entity in question.

In the context of culture both as goods and as tools, the workings of polysystem can remind the translation researcher of a chess game. Before delving into a straightforward hypothesis, however, it must be noted that within such a context, Even-Zohar uses 'culture' and 'literature' interchangeably in a function-based theorizing (cf. Even-Zohar 2002a). Thus,

\footnotetext{
${ }^{4}$ Here, I am referring to Vladimír Macura’s $(1990,2010)$ interpretation of "culture as translation."
} 
regardless of a cultural group's positioning in the center or in the periphery, the labor involved in making a repertoire "eventually creates motion of some scale, i.e., a socio-cultural energy" (Even-Zohar 2002a, 46). Instrumentalizing a national symbol such as the one in question crystallizes the resonation between cultural planning and the immediate resistance to a particular repertoire even on the lexical level. This first couple of translations within the present study's corpus fit into this argument like a glow. In Even-Zohar's words,

[I]f you are in a periphery, anything you do, i.e., your whole repertoire is, by definition, inferior to that of the center, because those in the center always master it better than you do, and also take the liberty of augmenting and changing it more freely than you. If you speak the 'same language', as it were, the language of the center will still sound a bit different. $(2000,400)$

Yet, the power relation between the two deterministic categories is not necessarily limited to this notion of superiority and inferiority. For instance, using the translation published by the ministry as the benchmark that makes and maintains the repertoire of the center, the rest of the translations in fact reveal some sort of self-defense of fair competitors in the paratextual and peritextual discourse. Thus, while striving for "access to options from which they have been previously deprived or barred" (Even-Zohar 2002a, 46-47), those translations arguably in the periphery repertoire do not suggest force majeure that "they all were equally humiliated or underprivileged, but that they all had less access to resources than what were their expectations" (47). Nevertheless, considering the circumstances under which renewal of resource allocation in respect of socio-cultural energy took place, the availability of discourses rests not only on bi-systemic competition but also on involvement from an outside source of energy. Therefore, it is evident that this system requires another concept for explanation, which can be verbalized as "complexity" according to Even-Zohar.

Unlike "heterogeneity, multiplicity or variety as such," Even-Zohar defines complexity as "a very specific variable that emerges out of a state of multiple choices to provide solutions for coping with changing or unrecognized circumstances" $(2016,19)$. From the perspective of the culture as tools approach, striving for meaning-making in changing or unrecognized circumstances entails "resentment and rejection of new repertoires," because the prospects of reaching a settlement between competitive forces are not high, or probably there always remains a group that considers itself to be the disadvantaged party (27). The competition in "the industry of ideas" that is plainly observed between innovators and conservers of the past still 
continues today not with regards to innovations demanding "legitimacy of . . equal footing" (28), but to "possessing and monopolizing the same assets" (Even-Zohar 2020, 239). Thus, what Even-Zohar indicates by "competition over resources via contests for symbolic capitals" applies perfectly well to the symbolic capital the source text of the present study carries in the target system, as he puts it:

A large bulk of the traditional goods are losing their value, but nevertheless are converted into assets for a completely different domain, which in some indirect way may still work for the sought-for prestige. I am referring to the conversion of the large inventory of spaces and objects labelled heritage into profitable merchandise used for attracting tourists with the purpose of generating profits. $(2020,245)$

Given the number of retranslations and books devoted to the subject matter, Gökalp surely proves a profitable merchandise with at least two sets of goods: one that of translating Gökalp for an Anglophone audience ${ }^{5}$ and the other, translating Gökalp back for a Turkish readership.

\section{Uriel Heyd's Foundations of Turkish Nationalism: The Life and Teachings of Ziya Gökalp: A Translator's Views on the Work of Another}

For a descriptive-explanatory analysis of translations, translational relationships and the functional-relational concept of translation should be reconstructed within a system. Therefore, this part of the paper will strive to reveal the context of the relationship between source and target texts. Given the canonized position of the source text ${ }^{6}$ in the target system, I will first analyze the source text author and the text.

Jacob M. Landau (2004), the renowned historian of Ottoman ideologies and Turkish nationalism, introduces Heyd as "the father of Turkish studies in Israel" (181). A most prominent orientalist, Heyd was born in 1913 in Cologne, Germany. Aharon Layish (1982) gives precise information on his studies on law and economics in various German universities and expresses that Heyd was encouraged to study Turkish and Persian by his uncle, the orientalist Dr. Kurt Levy. Given the circumstances of the political situation in Europe, he

\footnotetext{
${ }^{5}$ Surprisingly, the two translations of Gökalp's works into English, i.e., Turkish Nationalism and Western Civilization (1959) by Niyazi Berkes and The Principles of Turkism (1968) by Robert Devereux, have not been analyzed from a systemic and descriptive stance. The author of the present study hopes to conduct such an analysis in the future.

${ }^{6}$ Halil İnalcık (1969) considers this study as "the product of critical analysis" and "the most pivotal work on Ziya Gökalp published in a Western language" (115).
} 
migrated to Palestine in 1934 and gained a master's degree in history, mainly working on Islamic culture, Arabic language, and culture and history of Palestine (Layish 1982, 35). After graduating, he continued his research and went on to study Turkish language, literature, and history at Istanbul University in 1939 and 1940, during which period he stayed with a Turkish imam's family. In 1946, while working at the London office of the Jewish Agency for Palestine, he completed his study on Gökalp, which was accepted as a $\mathrm{PhD}$ thesis by Hebrew University. During his stay in London, Heyd lectured on the history of Ottoman Empire and studied old Turkish, Persian, and Urdu at the School of Oriental and African Studies (SOAS) at the University of London. Following his studies in London, he served as part of corps diplomatique at the Israeli Embassy in Washington and Israeli Legation in Ankara (36).

A "beacon of academic leadership" for a generation of academics specializing in the history of the Middle East, particularly Muslim peoples, Heyd was keen on teaching both graduate and postgraduate students Arabic language and literature following his own philological learning at SOAS (Cohen 2018). Layish (1982) also states that during his tenure at the Institute of Asian and African Studies at Hebrew University, Heyd initiated and headed the publication of Translation Series from Hebrew to Arabic and vice versa (36). His translation of Mahmut Makal's Bizim Köy ${ }^{7}$ (Our village) into Hebrew happens to have come out in 1951, the year he joined the faculty of Hebrew University. Having studied the ulema's attitude towards modernization and Westernization in the Ottoman lands in his master's thesis, most of his work is centered on Turkish nationalism, Islamic mysticism, and canon law. His book titled Language Reform in Modern Turkey (1954) is one of the most cited works on the modernization of Turkish language and adoption of the Latin alphabet.

As for the structure of the source text in this corpus, Foundations (1950) is divided into three parts on Gökalp's life, focusing on his formative years, his teachings, and his appreciation of science, poetry, and nationalism, respectively. The book additionally contains a foreword by Sir Wyndham Deedes, himself an intriguing translator, a preface by the author as well as a bibliography of works by Gökalp, and the books and articles that focus on him as the subject

\footnotetext{
${ }^{7}$ Makal's Bizim Köy was translated into English as A Village in Anatolia (1954) by the very same Wyndham Deedes, who wrote the foreword for Heyd's book. İhsan Akay (1956) reflected on the reasons for translation of this work in a timely article and considered it to be an outcome of politics rather than a recognition of literary merit. Landau (2004) states that Heyd's translation of Bizim Köy is the first Hebrew translation of a Turkish novel (185). The author of the present study hopes to conduct a systemic analysis on the position of translations from Turkish concerning the first half of the twentieth century.
} 
matter. Part 2 on his teachings has six subheadings in total, intricately categorizing Gökalp's views on topics of sociology, Westernization, Islam, and Turkism. As the descriptive analysis below will exhibit in detail, translations differ in conveying this material since different versions imbued with dissimilar ideological motivations specifically portray translation strategies that aim for resisting the authority attributed to the interpretation by an earlier version. At this point, the context in which these translations appeared requires explication.

\section{The Position of Retranslations in a Modern System}

\subsection{Türk Ulusçuluğunun Temelleri (1979) and Kadir Günay}

The very first translation of Heyd's Foundations titled Türk Ulusçuluğunun Temelleri (Foundations of Turkish nationalism) was published in 1979. The translator and the publisher are salient figures in the interpretation of this work, since the book is translated by Kadir Günay and published by the Turkish Ministry of Culture as the tenth book of the Science Series. ${ }^{8}$ The first few pages bear an introduction to the series by the then minister of culture, Ahmet Taner Kışlalı. ${ }^{9}$ The introduction highlights that the unity in perception, thought, and attitude of a nation is shaped by its distinctive circumstance and hence, 'culture' has a national identity. Still, the fact that disparate societies embrace some kindred circumstances and that these circumstances increase in number shed light on the universality of culture (Günay 1979, 5). In addition to the foreword and the preface, this version provides a "Notes" section that gives information on the who's who for the famous figures mentioned in the book, including Émile Durkheim and Mehmet Fuat Köprülü, brief explanations on philosophical traditions, and curious intralingual translations for rather 'old-fashioned' expressions such as 'ibda' (creation), 'lugat' (words), 'örf' (customary or unwritten law), and 'seciye' (character). This work does not provide any information on the translator.

\footnotetext{
${ }^{8}$ Other books in the Science Series include intralingual translations of classical works such as Tacü- $t$ Tevarih (Crown of stories), Tarih-i Bosna (History of Bosnia), Türk Tiyatrosunda Komedyanın Evrimi (Evolution of comedy in Turkish theater), and Çocuklara Ögü̈ller (Advice to children) as well as a translation of C. Wright Mills's Sociological Imagination by Ünsal Oskay and Roland Barthes's Éléments de sémiologie (Elements of Semiology) by Berke Vardar and Mehmet Rifat.

${ }^{9}$ This translation had a first run of one hundred thousand copies, suggesting that the book was not translated and published for commercial purposes only, but to be distributed as well.
} 


\subsection{Ziya Gökalp’ın Hayatı ve Eserleri (1980) and Cemil Meriç}

A second translation of Heyd's Foundations appeared in less than a year's time. Merely a couple of months following the military coup, a book bearing the title Ziya Gökalp'ın Hayatı ve Eserleri (The life and works of Ziya Gökalp) in bold enough characters with the caption "Cemil Meriç from Uriel Heyd" was published by Sebil. The structure of the book requires closer attention as some subsections of the source text are summarized in part 2; namely, the subsection of "Ideal” explaining Gökalp's views on Durkheim's sociology and the subsections on "Westernization" are outlined under a single subheading titled "Nasıl Bir Batılılaşma?" (What kind of Westernization?), and finally, all the poetry quoted in the subsection “Gökalp's Attitude to Religion" is completely omitted. In addition, Meriç's choice for naming of each part is quite marked. While part 2 is titled "Gökalp'den Kalan” (What remains from Gökalp), part 3 is titled "Değer Hükmü" (Value judgment). Because the descriptive analysis below will lay bare the details of this textual segmentation, now this study will explicate Meriç's political standpoint briefly.

A well-known author with a labyrinthine-like mind and contentious political views still debated by both left- and right-wing intelligentsia, Meriç has a tumultuous life story. His family emigrated from Greece to Hatay after the Balkan Wars. The region was then under French mandatory rule, and after a short period of independence, it was annexed by Turkey in 1939 . Born in 1916, the political transformation he observed was influential on his cultural-linguistic views. After he left French High School in Antakya, he continued his study at Pertevniyal High School and eventually studied French at Istanbul University. ${ }^{10}$ Introducing himself as a mind ruminating on translation in a letter addressed to Ferit Edgü, he states that he understands Arabic and Persian, knows French, and reads English (Meriç [1993] 2008, 323). Unsurprisingly, his heritage projecting onto his "devotion to what is considered by some as old language" (324) made him a questionable figure on the intellectual scene. As Anat LapidotFirilla suggests,

The French saw his interest in Ottomanism as a political statement favoring the unification of Hatay with Turkey. The Kemalists saw his linguistic preferences for the Ottoman heritage as evidence of his unwillingness to join the secular modernization

\footnotetext{
${ }^{10}$ For his life story and the complete list of his works, see İletişim Publishing’s page for "Cemil Meriç." In 2016, İletişim launched a series devoted to all his translations, starting with Altın Gözlü Kız (The Girl with the Golden Eyes) by Honoré de Balzac ("Cemil Meriç," Iletişim, accessed March 30, 2020, https://www.iletisim.com.tr/kisi/cemil-meric/4901\#.VHRrNIusX6Q).
} 
project and consequently as an intellectual threat. $(2011,125)$

Yet, his views on modernization had deeper signifieds compared to his linguistic preferences. According to Gürbilek (2011), he was “one of the harshest critics of Republican ideals [who] exalted sometimes the Ottoman of the past and sometimes a broader East" (173). Thus, the manifest intertwining of political views with linguistic entities is what makes his translation strategy a remarkable example of rare intuition.

Meriç's translation strategy ${ }^{11}$ can be reconstructed through his choice of lexicon as he argues that "the struggle today 'is not between man and fate' but rather, 'between man and the word"” (Lapidot-Firilla 2011, 127). In this respect, his rebuttal of two-edged politics of modernization and obscurantism, in his own words, "the coquette" the West attributed to 'us,' apparently reflects his approach to 'asrîleşmek' (to become modern), as he puts it:

Modernization, or in its literal (Turkish) sense "contemporization," is the new European commodity for export, like cocain and LSD...a poison that paralyzes consciousness. The accusation of lagging behind the contemporary world is the most despicable of slanders, and the most absurd. Various ages co-exist within the same age. Why should contemporization necessarily mean adoration of the idols of the Christian West? (Meriç 2011, 136-137)

This quote explains the translator's choice of work and the precarious context in which the book was translated and published. Moreover, it is without doubt ${ }^{12}$ a very Meriç way of resisting to an authoritarian regime, for, in his eyes, "eternal freedom to thought" (Meriç 2011, 136) can only be achieved with books.

\subsection{Türk Milliyetçiliğinin Kökleri (2001) and Adem Yalçın}

The third translation of Heyd's Foundations was published in 2001 with the title Türk Milliyetçiliğinin Kökleri (Roots of Turkish nationalism). The translator of the book, Adem Yalçın, also translated Mark Juergensmeyer's The New Cold War? into Turkish, which was published by the same publishing house, Pinar. The publisher's catalogue of publications focuses on books related to Islamic theology, including The Life of Prophet Mohammed, history, and politics. The structure of the book is similar to that of the source text in terms of

\footnotetext{
${ }^{11}$ For a discussion of visibility of Meriç as a translator, see Karadağ 2011.

12 In an article titled "İki Farklı Tercüme" (Two discordant translations), Arslan Tekin (2018) asks whether Meriç is the genuine translator of the book in an ironic manner and adds that some of the statements in Günay's translation were not censored by the ministry during the government led by Bülent Ecevit. However, Meriç ([1993] 2008) mentions Heyd's book as one of his latest translations in his memoirs titled Jurnal (Journal) (vol. 2).
} 
foreword, preface, and footnotes. Only the blurb at the back cover hints at the political standpoint of the publisher, as it highlights Gökalp's identity as one of the moral founders of the Turkish Republic. Nevertheless, the blurb touches on his "borrowing" of thoughts largely from Europe and indicates that Gökalp did not appeal to rules of logic most of the time, yet could present an approach as to how Western thought, tradition, and methods could be best applied to the institutions of his own country.

\subsection{Türk Ulusçuluğunun Temelleri (2002) and Kadir Günay}

The fourth translation within the corpus is what Koskinen and Paloposki (2019) call a non-retranslation, for it is a reprint of the 1979 translation by Günay. However, this time, the introduction to the specific work of translation by the minister of culture, İstemihan Talay, and a short biography of the translator on the back cover, accompanied by a blurb, reveal more about the translation policy of the ministry. ${ }^{13}$ Surprisingly, the reprint came out again when Bülent Ecevit held office as the prime minister in 2002. In his introduction, Talay underscores the significance of Heyd's book at a time when the integration with the European Union gains speed. The biography of the translator reveals that Günay received high school education at Notre Dame International School in Rome and further on majored at Ankara University's Department of Economics. Also, he mainly worked at senior positions of state institutions, including State Investment Bank, Treasury, and the Office of Prime Minister. During the time of publication, he was a board member of Ziraat Bank. As for the structure of the book, nothing is changed compared to the first edition.

\subsection{Türk Milliyetçiliğinin Kökenleri (2010) and A. Göke Bozkurt}

The most recent translation of Foundations was published by İlgi Kültür Sanat. The translator of the book, A. Göke Bozkurt, has also translated numerous classics of English and Russian literature as well as books on history including Charles H. Sherrill's A Year's Embassy to Mustafa Kemal as Selanik'ten Gelibolu'ya (From Thessaloniki to Gallipoli). The publisher's selection criteria for this particular work can be evidently observed from the publication

\footnotetext{
${ }^{13}$ This time the reprint is published under the World Literature Series in the catalogue of publications by the Ministry of Culture.
} 
catalogue that contains works by Yusuf Akçura ${ }^{14}$ and Ziya Gökalp. The website of the publisher declares that in their work, they are devoted to the principles and vision of protecting the invaluable heritage of centuries-old Turkish culture as an inseparable part of civilization as well as embracing the founding values of the Turkish Republic. Against bigotry in terms of religions, languages, race, gender, and color of skin, the publisher expresses that they are concerned with the monuments of all people. ${ }^{15}$ The structure of this translation is different compared to other translations. The foreword by Deedes is omitted; instead, there is an introduction by Mustafa Alican on Heyd and his works. As Alican remarks in this part upon a tripartite interpretation of Heyd's book,

This text shows us that a synthetic judgment formed after a series of correct analyses is not necessarily truthful and points to inconveniences that result from constructing historical facts from generalizations built on "deliberately chosen fragments." (Bozkurt 2010, 20; my translation; emphasis mine)

In his interpretation on the face of the identity of the author, Alican goes as far as to suggest that Heyd's academic work and his contributions to the discipline of history "whisper to us that such a discourse analysis is the product of a conspirator's mind" (Bozkurt 2010, 14; my translation). After this cautionary introduction, the reader is confronted with the preface by the author himself. Apart from this riveting opening, the segmentation of parts and subheadings is similar to Yalçın's translation.

At this point, the comparative descriptive analysis below will lay bare the covert aspects of each translation. The irony in publishing a work of translation with cautionary remarks and censored parts not only amplifies discursive conflicts but also provides empirical data for translation research to sink in the notions of adequacy and acceptability in respect of translation of Turkish nationalism into English and its backtranslations.

\section{Retranslations of Foundations of Turkish Nationalism: The Life and Teachings of Ziya Gökalp}

Starting the descriptive analysis with the preliminary norm, I will attempt to reconstruct

\footnotetext{
${ }^{14}$ François Georgeon's book on Akçura titled Aux Origines du Nationalisme Turc: Yusuf Akçura (1876-1935) (The roots of Turkish nationalism: Yusuf Akçura (1876-1935)) complicates the reception of Heyd's book, as both books bear the same title in Turkish, i.e., Türk Milliyetçiliğinin Kökenleri (Origins of Turkish nationalism), in my opinion.

15 “Hakkımızda"(About us), İlgi Kültür Sanat, accessed March 30, 2020, https://www.ilgikultur.com/sayfa/hakkimizda.
} 
the translation policy for the selection of the work in question for translation in a political historical framework. The purpose of commissioning of the first translation is definitely embedded in the context of political turmoil Turkey went through in the 1970s, but particularly at the end of the decade. ${ }^{16}$ Given the canonized nature of the source text, therefore, the second translation appearing within a year's time following the initial one can be attributed to an oppositional position. After the appearance of a third translation on the stage, the republication of the initial translation by the ministry during a period when the same prime minister, Ecevit, was holding the office can be considered a symbolic act of systemic maintenance. It should be noted that all translations were published during periods when terror in the southeast of Turkey was a major political consideration. Thus, the deliberation on what it means to be 'Turkish' and the fierce discussions on who belongs to the included and the excluded categories of a national entity were raging. The timing of the last translation can be undoubtedly interpreted as a political act, for, in 2009 , it was publicized that a democratic initiative process aiming for a Kurdish opening was underway.

In view of the political climate, the initial norm can be reconstructed on the results gathered from the paratextual analysis above. Using the initial norm simply as an "explanatory tool" (Toury 2012, 80), the first cautionary point to keep in mind in Gideon Toury's words is that micro-level decisions "by no means" need to correlate with macro-level decisions; hence, "encountering $100 \%$ regularity should arouse immediate suspicion as being too good to be true" (81). Yet, at this stage, the translation by Günay seems to present an adequate translation in terms of its representative value. The second one by Meriç implies an annotative translation, highlighting the translator's views on the work, as the caption "Cemil Meriç from Uriel Heyd" suggests. Interestingly, the third translation also signals adequacy as the initial norm. Skipping the fourth translation, that is the reprint of Günay's initial translation, the final translation definitely creates the expectation of an acceptable translation. Without further due, the analysis will continue with operational norms.

The first category of operational norms is matricial norms covering the fullness of translations and segmentation of the work into paragraphs, passages, and the like. Meriç's translation is dramatically different in this respect compared to all the other translations, as he

\footnotetext{
${ }^{16}$ For a historical discussion of the period, see Ümit Cizre's article titled "Ideology, Context and Interest: The Turkish Military" and Hamit Bozarslan's article on political scene and the Kurds titled "Kurds and the Turkish State" in Kasaba 2008.
} 
summarizes most of part 2 under the subheading "Nasıl Bir Batılılaşma?" (What kind of Westernization?). The whole text does not follow the source text segmentation either, displaying sometimes an unfounded strategy of splitting and combining two paragraphs (Meriç 1980, 39, 45, 57), whereas Günay and Yalçın keenly observe the source text segmentation. In Meriç's translation, there are no footnotes whatsoever. Yet, the translator apparently chose to relay a number of them in the text itself in parentheses. There is a particularly interesting example for such a footnote. Advocating a new "science of the social roots of the [canon] law," Gökalp attempts to formulate a method for separation of 'örf,' which Heyd explains as "the collective consciousness of society" $(2010,86)$. In the following pages, the footnote referring to H. A. R. Gibb's criticism on Gökalp's views on the matter as "purely subjective" (88) is translated by Günay most literally $(1979,104)$. While Meriç inserts the footnote right into the text in parentheses indicating merely Gibb's criticism without referring to any source (1980, 63), Yalçın provides it at the end of part 2, unfortunately with the false number, though (2001, 177). Furthermore, in Meriç's translation, all poetry by Gökalp is omitted except for a few titled “Şaki İbrahim'in Hikayesi” (Epic of İbrahim the bandit) (1980, 23), a couple of stanzas (38), and two couplets from pan-Turkic poems (92-93). Still, Günay and Yalçın provide all poetry from the source text.

The most pivotal changes in all the translations are omitted passages, summarization, and an example of self-censorship. Meriç's strategy in omitting one of the most significant aspects of Gökalp's theorizing on culture and civilization is striking. Unusual in view of the sui generis identity of the translator, Meriç $(1980,44)$ omits the passages covering Heyd's explanation for the etymology of the word "culture" and how it was borrowed from French as well as the cause of failure of Westernization during Tanzimat (54). Table 1 below displays Meriç's solution to a problem comparatively.

Table 1. Summarization

Source text (Heyd 1950)
Having found the basis of nationality to be in culture, Gökalp is at pains to define this term. He is aware that every nation possesses spiritual and material values which are not peculiar to it but are common to different nations. Such values are excluded from culture (hars), which in Gökalp's definition is entirely national, and are called civilization (medeniyet), to which an international character is attributed. The distinction between these two terms, which play a major role in Gökalp's theories, is mainly formal. Gökalp regards as part of culture all feelings, judgments and ideals, while 


\begin{tabular}{|c|c|}
\hline & $\begin{array}{l}\text { rational and scientific knowledge, methods and technology are considered } \\
\text { as belonging to civilization. This definition leads him to give culture an } \\
\text { emotional and subjective character. On the other hand, values of } \\
\text { civilization have mainly an intellectual, objective, practical and often } \\
\text { material character. (63) }\end{array}$ \\
\hline \multirow{2}{*}{$\begin{array}{l}\text { Target text } 1 \\
\text { (Günay 1979) }\end{array}$} & $\begin{array}{l}\text { Ulusun temelini kültürde bulan Gökalp bu deyimi tanımlamakta büyük } \\
\text { güçlük çekmiştir. Her ulusun manevi ve nesnel değerlere sahip olduğunun, } \\
\text { bunların sadece bir ulusa özgü olmayıp çeşitli ülkelere müş̧terek özellik } \\
\text { gösterdiğinin farkındadır. Gökalp'in uluslararası nitelikte gösterdiği ve } \\
\text { medeniyet adı verdiği bu değerler, tamamen ulusal nitelikteki kültür (hars) } \\
\text { tanımının dışında tutulmuştur. Gökalp'in teorilerinde çok önemli bir yeri } \\
\text { olan bu iki sözcük arasındaki fark esas bakımından biçimseldir. Gökalp } \\
\text { bütün duyguları, yargıları......ve ülküleri kültür tanımı içinde sayarken } \\
\text { mantıki ve bilimsel yöntemlerle teknoloji ve bilgiyi uygarlık kapsamına } \\
\text { sokmuştur. Bu tanımlama ile, kültüre daha çok duygusal ve subjektif bir } \\
\text { özellik vermiştir. Öte yandan, uygarlık içine alınan değerler, akla dayanan, } \\
\text { objektif, pratik ve çoğu kez nesnel niteliktedir. (75) }\end{array}$ \\
\hline & $\begin{array}{l}\text { (Gökalp, who found the foundation of the nation in culture, had great } \\
\text { difficulty in defining this concept. He is conscious that every nation has } \\
\text { spiritual and material values, which are not unique only to a nation but have } \\
\text { features common to various nations. These values, which Gökalp presents } \\
\text { as of international quality and which he calls civilization, are excluded from } \\
\text { the definition of culture (hars) that is exclusively of national quality. The } \\
\text { difference between these two words, which have a very important place in } \\
\text { Gökalp's theories, is essentially formal. While Gökalp counts all feelings, } \\
\text { judgments......and ideals within the definition of culture, he considers } \\
\text { technology, knowledge, and logical and scientific methods in the scope of } \\
\text { civilization. With this definition, he has attributed culture more emotional } \\
\text { and subjective traits. On the other hand, values embraced by civilization } \\
\text { are rational, objective, practical, and often objective.) }\end{array}$ \\
\hline \multirow{2}{*}{$\begin{array}{l}\text { Target text } 2 \\
\text { (Meriç 1980) }\end{array}$} & $\begin{array}{l}\text { Milletin temeli harstır. Gökalp, milletlerarası kıymetlere medeniyet adını } \\
\text { verir. Hisleri, hükümleri, mefkûreleri harsa dahil eder. Aklı, ilmi, bilgiyi, } \\
\text { metodları ve teknolojiyi medeniyetin cüzleri sayar. Harsın hissî ve enfüsî } \\
\text { (sübjektif) bir mahiyeti vardır. Medeniyete ait kıymetler ise fikrî, afakî } \\
\text { (objektif) amelî ve çok defa maddî bir mahiyet arzeder. Harsî kıymetler, } \\
\text { cemiyetin şuur altında gelişir. (41) }\end{array}$ \\
\hline & $\begin{array}{l}\text { (The foundation of the nation is culture (hars). Gökalp calls international } \\
\text { values civilization. He includes feelings, judgments, and ideals within } \\
\text { culture. He counts the mind, science, knowledge, methods, and technology } \\
\text { as the parts of civilization. Hars has a sensual and subjective nature. On the } \\
\text { other hand, the values belonging to civilization have intellectual, apathetic }\end{array}$ \\
\hline
\end{tabular}

\footnotetext{
${ }^{17}$ All backtranslations in tables are mine.
} 


\begin{tabular}{|l|l|}
\hline & $\begin{array}{l}\text { (objective), and often material characteristics. The cultural values develop } \\
\text { under the consciousness of the society.) }\end{array}$ \\
\hline $\begin{array}{l}\text { Milliyetin temelinin kültürde olduğu hükmüne varan Gökalp, bu kavramı } \\
\text { tanımlamak için büyük çaba sarf eder ve özen gösterir. O, her milletin } \\
\text { sadece kendine has olmayan ve fakat farklı milletler için müsterek olan } \\
\text { maddi ve manevi değerlere sahip olduğunun farkındadır. Bu tür değerler, } \\
\text { Gökalp'ın tanımına göre tamamen milli olan kültürün (hars) dişındadır ve } \\
\text { beynelmilel bir karakter atfedilen medeniyete dahildir. Gökalp'in } \\
\text { teorilerinde önemli bir rol oynayan bu iki kavram arasındaki fark temelde } \\
\text { biçimseldir. Gökalp bütün hisleri, yargıları ve idealleri kültürün parçası } \\
\text { olarak telâkki ediyorken, akli ve bilimsel bilgiyi, metotları ve teknolojiyi } \\
\text { medeniyete ait olarak mütâlaa etmektedir. Bu tanım onu, kültüre duygusal } \\
\text { ve subjektif bir karakter kazandırmaya götürür. Diğer taraftan, medeniyetin } \\
\text { değerleri temelde entelektüel, objektif, tatbiki ve çoğu zaman da maddi } \\
\text { karakter arz eder. (71-72) } \\
\text { (Yalçı 2001) }\end{array} \mid \begin{array}{l}\text { (Having come to the conclusion that the foundation of nationality is in } \\
\text { culture, Gökalp makes great efforts and pays strict attention to define this } \\
\text { concept. He is aware that every nation has material and moral values that } \\
\text { are not only unique but common to different nations. Such values are } \\
\text { outside the culture (hars), which is exclusively national according to the } \\
\text { definition of Gökalp, and are included in civilization which is attributed an } \\
\text { international character. The difference between these two concepts, which } \\
\text { play an important role in Gökalp's theories, is basically formal. While } \\
\text { Gökalp regards all feelings, judgments, and ideals as part of culture, he } \\
\text { considers mental and scientific knowledge, methods, and technology } \\
\text { belonging to civilization. This definition leads him to give the culture an } \\
\text { emotional and subjective character. On the other hand, the values of } \\
\text { civilization have basically intellectual, objective, practical, and often } \\
\text { material characteristics.) }\end{array}$ \\
\hline
\end{tabular}

In addition, Meriç opts for summarizing the passages on Gökalp's criticism of Alfred Fouillée's views on monism, determinism, and the source of individualistic creativity (1980, 34), whereas Günay (1979, 52-55) and Yalçın (2001, 52-55) translate literally. Lastly, a paradoxical example of self-censorship concerning Mustafa Kemal's attitude to separation of state and religion is found in all translations (cf. Tekin 2018). Heyd's (1950) statement "[b]ut for the anti-Islamic attitude of Atatürk" (82) is translated by Günay (1979) most literally as "Atatürk'ün dine karşı tutumu olmasaydı" (97; if it was not for the anti-religious attitude of Atatürk; my translation), while Meriç (1980) favors a circumspect way of putting it as "[f]akat o çağdaki İslamiyet aleyhtarı bazı davranışlara kıyasla" (59; yet, in comparison to some antiIslamic actions in that age; my translation) and Yalçın (2001) provides an innovative solution 
to the censor constraint as he conveys this statement as "[f]akat Atatürk zamanındaki devrimlerin katkısıyla" (92; however, thanks to the reforms undertaken at the time of Atatürk; my translation).

The second category of matricial norms is textual-linguistic norms. The marked discourse of what is recognized as 'old' and 'modern' is a straightforward position the first two translators anxiously underscore. In Even-Zohar's (1990) terms, "renovated language" (47) functions clearly as a product of absolute target-orientedness, ${ }^{18}$ hence almost creating a resemblance between the works by Günay and Meriç as intralingual translations of one another. On this matter, Tuncay Birkan (2020) asserts that "the words that had an Arabic or Persian origin were deemed 'right-wing' while the 'pure Turkish' ones were seen, in a curious irony of history, as "left-wing'" (24). Without a doubt, opting for certain equivalents of one another, both Günay and Meriç were performing an act of abidance and resistance by analogy. On the other hand, the examples given in this study reflect that the translation by Yalçın seems to negotiate between the two stances on language by combining them, once again displaying the ends of an accidental wit solely language can accommodate.

Ironically, an unintelligible strategy is found in the backtranslation of Heyd's direct reference to Gökalp in English. While Günay this time resorts to what is considered 'old,' Meriç tends to favor a more 'modern' register one expects to find from him. In this respect, table 2 exhibits the workings of an ironic fallacious reasoning of a philosophy of language.

Table 2. The dilemma of 'old' and 'modern'

\begin{tabular}{|l|l|}
\hline $\begin{array}{l}\text { Source text } \\
\text { (Heyd 1950) }\end{array}$ & $\begin{array}{l}\text { In his article Yeni Hayat ve Yeni Klymetler [New life and new values], } \\
\text { published in 1911, he makes the statement that "humanity finds its } \\
\text { expression to-day in the notion of nationality." (59) }\end{array}$ \\
\hline $\begin{array}{l}\text { Target text 1 } \\
\text { (Günay 1979) }\end{array}$ & $\begin{array}{l}\text { Yeni Hayat ve Yeni Kiymetler adlı makalesinde "Bugünkü insaniyeti } \\
\text { milliyet mefhumunda mütecelli gördüğ̈ için" demektedir. (70) } \\
\text { (In his article titled "Yeni Hayat ve Yeni Kiymetler," he states that } \\
\text { "humanity today is manifested in the notion of nation.") }\end{array}$ \\
\hline $\begin{array}{l}\text { Target text 2 } \\
\text { (Meriç 1980) }\end{array}$ & $\begin{array}{l}\text { 1911'de yayınlanan "Yeni Hayat ve Yeni Kiymetler" adli makalesinde, } \\
\text { "bugün insanllk kendi ifadesini milliyet mefhumunda bulmaktadır", der. }\end{array}$ \\
\hline
\end{tabular}

\footnotetext{
${ }^{18}$ For a discussion on intralingual translation and ultimate target-orientedness, compare Even-Zohar 1990, 241251; Ertürk 2008, 2011; Heyd 1954; Lewis 1999.
} 


\begin{tabular}{|l|l|}
\hline & $\begin{array}{l}\text { (40-41) } \\
\text { (In his article titled "Yeni Hayat ve Yeni Kiymetler" published in 1911, he } \\
\text { states that "humanity today finds its expression in the notion of nation.") }\end{array}$ \\
\hline $\begin{array}{l}\text { Target text 3 } \\
\text { (Yalçın 2001) }\end{array}$ & $\begin{array}{l}\text { "Bugünkü insaniyet milliyet mefhumunda mütecelli gördüğ̈ için" } \\
\text { ifadesini kullanır. (67) } \\
\text { (In his article "Yeni Hayat ve Yeni Kiymetler" published in 1911, he utters } \\
\text { that "humanity today is manifested in the notion of nation.") }\end{array}$ \\
\hline
\end{tabular}

Table 3 below outlines the textual properties of all translations.

Table 3. Textual properties

\begin{tabular}{|c|c|}
\hline Translator & Content of the translation \\
\hline Günay (1979) & $\begin{array}{l}\text { Conveys the foreword by Deedes and the preface by Heyd. } \\
\text { This translation has an introduction signed by the minister of culture. } \\
\text { All the parts and subsections of the source text are literally translated with } \\
\text { the who's who list by the author provided at the back under the "Notes" } \\
\text { heading. }\end{array}$ \\
\hline Meriç (1980) & $\begin{array}{l}\text { Conveys the foreword by Deedes and the preface by Heyd. } \\
\text { This translation does not bear an introduction and largely summarizes part } \\
2 \text { of the source text. } \\
\text { This version does not reproduce the who's who list at the back. }\end{array}$ \\
\hline Yalçın (2001) & $\begin{array}{l}\text { Conveys the foreword by Deedes and the preface by Heyd. } \\
\text { All the parts are translated with footnotes. } \\
\text { This translation is dedicated to the translator's wife. } \\
\text { The cover has the modern Turkish flag. }\end{array}$ \\
\hline Günay (2002) & $\begin{array}{l}\text { A reprint of } 1979 \text { translation with the addition of an introduction by the } \\
\text { then minister of culture. }\end{array}$ \\
\hline Bozkurt (2010) & $\begin{array}{l}\text { Has an introduction by Alican and a preface by Heyd. } \\
\text { This translation includes the who's who list provided by Heyd under the } \\
\text { heading "Dictionary" at the end. } \\
\text { The cover portrays a horizon full of flags and banners invoking the } \\
\text { traditional battleground scene at the background with an image of three }\end{array}$ \\
\hline
\end{tabular}


crescents and a star symbolizing the Turkic khaganate known as Gokturks on the front.

All in all, does the initial norm correspond to the matricial norm? Does the empirical analysis refute the inceptive hypothesis? Apparently, Günay's translation proves the initial expectation for an adequate translation correct while Meriç's satisfies the expectation for an acceptable translation. On the other hand, the strategies of the remaining two translations point to a macro-level norm internalized by probably larger audiences of producers and consumers of translation. That is, there seems to be an unquestioned understanding that the producer of a translation can wield the audience's interpretation through paratextual entities such as covers, introductions, and prefaces, yet the main body of the translated text must follow strict rules of a considerably adequate rendering.

\section{A Comparative Systemic Analysis of Retranslations}

At this point, coming to the questions the present study problematizes for future research on retranslations, it is reasonable enough to repeat our point of departure: What outcomes do modelling a pattern and comparative analysis yield for future prospects of retranslation research? In this light, the literature review reveals two descriptive studies on retranslations analyzing the same period to which the present case belongs; namely, Esra Birkan Baydan's (2008) work on Islamizing retranslations of children's classics and Ceyda Özmen's (2019) work on retranslations of a bibliography of Mustafa Kemal titled Grey Wolf. Because the present study focuses on a specific timeline, the systemic modelling will be based on comparing Özmen's descriptive analysis with the one presented here. Table 4 below summarizes the focal points of this comparative analysis.

Table 4. A comparative modelling of descriptive analyses on retranslations

\begin{tabular}{|l|l|}
\hline $\begin{array}{l}\text { Foundations of Turkish Nationalism: The } \\
\text { Life and Teachings of Ziya Gökalp (1950) }\end{array}$ & \multicolumn{1}{|c|}{ Grey Wolf (1933) } \\
\hline $\begin{array}{l}\text { Uncensored acceptable translation by Günay } \\
\text { published in book form in 1979 }\end{array}$ & $\begin{array}{l}\text { A partial and censored first translation by } \\
\text { Necmettin Sadik Sadak published in } \\
\text { serialized form in 1932 and in book form in } \\
1955\end{array}$ \\
\hline A self-censored annotative retranslation by & A self-censored covert retranslation by \\
\hline
\end{tabular}




\begin{tabular}{|l|l|}
\hline Meriç in 1980 & Peyami Safa in 1955 \\
\hline $\begin{array}{l}\text { A full retranslation with totally similar } \\
\text { elements of the previous versions by Yalçın } \\
\text { in } 2001\end{array}$ & $\begin{array}{l}\text { A full retranslation with "liberal } \\
\text { interpretation" by Gül Çağalı Güven in 1996 }\end{array}$ \\
\hline The non-retranslation by Günay in 2002 & $\begin{array}{l}\text { A partial retranslation with plagiaristic } \\
\text { elements by Ahmet Çuhadır in 2001 }\end{array}$ \\
\hline $\begin{array}{l}\text { A plagiarized retranslation from Günay's } \\
\text { translation published in 2010 (The cover } \\
\text { names the translator as Bozkurt.) }\end{array}$ & \\
\hline
\end{tabular}

Though it is difficult to identify a definite pattern in the initial stages of the comparative analysis, there seems to be certain characteristics that both analyses share. Considering the identity of the translators, it is apprehensible for Meriç and Safa to exercise self-censorship. Moreover, unpredicted groups of translations exhibit similar linguistic choice of register marginalizing the source text's authority. For instance, Özmen (2019) suggests that in Sadak's translation "the target text took the form of a conversation between two conflicting voices" (48). The same register of a dialogue or coming to terms or agreeing with the source text is also partially present in Meriç's translation, as he questions Gökalp's advice for acquiring Western methods and proper Westernization, in his own ironic tone: "Modern ilmin metodları ise Batının kitaplarından öğrenilebilirdi. Kendisi de öyle yapmamış mıydı? Ne diyelim..” (1980, 58; As for the modern scientific methods, it could be learned from European literature. Did not he do so? What shall we say...; my translation). As a final point, Özmen (2019) argues that "the inconsistent and unsystematic nature of censorship functioned not just as a repressive force but also as a promotive one" (60). Thus, censorship serves as a clear-cut parameter for a comparative systemic analysis similar to the one presented here.

\section{Conclusion}

The findings of the descriptive study above point to at least two working hypotheses, which can be generalized through comparisons with more descriptive analyses that examine retranslations published within the same time period. First of these is that for a certain period of time, probably before the dawn of the millennium, the initial norm indicated via the use of paratextual elements of a work corresponded with the matricial norm. Yet, though arguable at this point, it seems that the macro-level tendency in terms of what is considered to be an 
appropriate translation - in view of the definition of "translation equivalence" using Toury's concepts - is to aim for acceptability. The second hypothesis is related to the choice of vocabulary considered to be 'old' and 'modern.' In this light, the textual-linguistic norm of the most recent retranslation, i.e., the one published in 2001-since the translation published in 2010 is plagiarized from an earlier version - demonstrates that the socially-constructed abyss in the case of language use is narrowing down, because this version merges linguistic elements of both the earlier versions. On the face of the keen contradictory language choice of the previous translations, the 2001 retranslation is a perfect example of a satirically intertwined discourse mixing old language with the modern. Given these findings, we must ask if Berman's retranslation hypothesis and "non-traduction" are still pertinent. The answer lies once again in the space between lines and the historical foundation of the paradigms.

A perpetual loophole in terms of the scientific pursuit for retranslations is that the relevance of retranslation hypothesis and its epistemological sources, i.e., the German idealism underlying the nationalism, are never questioned. Thus, simply conducting descriptive studies that analyze the linguistic properties of retranslations cannot avoid producing ambiguous results in terms of systemic constellation. Studying unnecessarily foregrounded stress on language and oeuvre without analyzing the respective contextual framework cannot go beyond what Berman suggests: "Le schéma triadique de Goethe correspond grosso modo à la dialectique de l'Idéalisme allemand" (1990, 4; Goethe's triadic scheme approximately corresponds to the dialectic of German idealism; my translation). This approach to retranslation research simply confines the concept of translation to "domaine d'essentiel inaccomplissement" ( 1 ; the area of essential nonfulfillment; my translation) that, as Berman declares, is the characteristic of the field. Yet then a critical study would ask: Why consider something observable nonexistent? The answer may be lying inside the problem as Berman elaborates: "cette défaillance de la traduction qui menace éternellement toute culture" (7; this failure of translation that forever threatens any culture; my translation). The methodology for investigating Berman's understanding of 'toute culture' (any culture) is already available in translation studies. In respect of the workings of a polysystem, retranslation research might potentially function as a tool for a conceptualization of what Even-Zohar (2020) calls "a new and different repertoire, which we have not identified yet, may now be emerging" (245). Instead of looking for a solution for the verifiability of retranslation hypothesis, we shall rather further our thinking on two scenarios, that is, the case when the symbolic capitals do not serve for the proper functioning 
of the established system and when the system is not stable enough to provide for meaningmaking (cf. Even-Zohar 2020, 246-247).

Moreover, in case of the specific target system that is the topic of the present study, namely the Turkish target system, can we consider it stable enough to provide for a stock exchange of symbolisms? In light of this, Gürbilek elucidates:

[T] he repressed never returns as the repressed thing it was, as pure content emerging suddenly after a long silence ... it returns as something shaped by the needs of the site to which it returns, always reconstructed in different forms, open to new projects and manoeuvres, reformed according to the demands of the market or 'world politics', vulnerable to relationships of power and interest. $(2011,86)$

The repressed of the past challenges the traditional theorizing on systems. What a battered culture of post-neoliberalism requires is fine-grained approaches to translation studies in general, but particularly the research on retranslations. Time should be devoted to ask what modelling tools, categories, or parameters to use for systemic comparative analysis. Does "nonretranslation" work as an instrument of systemic maintenance? Thus far, we have analyzed the texts comparatively. Now it is time to challenge our patterns of retranslation analyses against theorizing on politics of nationalism, in other words, tools of power/culture against systems. ${ }^{19}$

\footnotetext{
${ }^{19}$ This also requires asking how the shared patterns obtained as a result of descriptive analyses could be visualized using Python given that the machine translation paradigms will undoubtedly be put to use in retranslation research. This makes the author of the present paper recall Meriç's (2011) epigraph devoted to books in Babel, quoting "Every society has its foundation in a book: the Ramayana, the Song of Songs, or the Qur'an. Which one is yours?" (141).
} 


\section{References}

Akay, İhsan. 1956. "Yabancı Dile Çevrilme." [Translated into a foreign language.] Varlık, no. 431,6 .

Berman, Antoine. 1990. "La retraduction comme espace de la traduction." [Retranslation as a translation space.] Palimpsestes, no. 4, 1-7. doi:10.4000/palimpsestes.596.

Birkan, Tuncay. 2020. "Needed and Needy: My Dictionary out of Dictionaries." Counterpoint, no. 3, 23-26.

Birkan Baydan, Esra. 2008. "Visibility of Translation through Conflicting Ideologies: The 'Islamic' Retranslations of '100 Essential Readings." Master's thesis, Boğaziçi University.

Bozkurt, A. Göke, trans. 2010. Türk Milliyetçiliğinin Kökenleri [Foundations of Turkish Nationalism: The Life and Teachings of Ziya Gökalp]. By Uriel Heyd. Istanbul: İlgi Kültür Sanat.

Butler, Judith, and Gayatri Chakravorty Spivak. 2007. Who Sings the Nation-State? Language, Politics, Belonging. London: Seagull Books.

Cohen, Amnon. 2018. "Our Mentor Uriel Heyd, a Beacon of Academic Leadership." Paper presented at the International Symposium on the Society and Law in the Ottoman Empire, Jerusalem, June 26-27.

Edwards, A. Cecil. 1951. Review of Foundations of Turkish Nationalism: The Life and Teachings of Ziya Gökalp, by Uriel Heyd. International Affairs 27 (1): 112-113. doi:10.2307/2608376.

Ertürk, Nergis. 2008. “Modernity and Its Fallen Languages: Tanpınar's Hasret, Benjamin's Melancholy." PMLA 123 (1): 41-56. https://www.jstor.org/stable/25501826?seq=1\#metadata_info_tab_contents.

2011. Grammatology and Literary Modernity in Turkey. Oxford: Oxford University Press.

Even-Zohar, Itamar. 1990. "Polysystem Studies." Special issue, Poetics Today 11 (1). https://www.tau.ac.il/ itamarez/works/books/Even-Zohar_1990--

Polysystem\%20studies.pdf.

. 1996. "The Role of Literature in the Making of the Nations of Europe: A SocioSemiotic Study." Applied Semiotics/Sémiotique appliquée 1 (1): 39-59. https://www.tau.ac.il/ itamarez\%20/works/papers/papers/EvenZohar_1996-The $\% 20$ Role $\% 20$ of $\% 20$ Literature $\% 20$ in $\% 20$ the $\% 20$ Making\%20 $\%$ 20the $\% 20$ Nati ons $\% 20$ of $\% 20$ Europe.pdf. 
2000. "Culture Repertoire and the Wealth of Collective Entities." In Under Construction: Links for the Site of Literary Theory; Essays in Honor of Hendrik van Gorp. Edited by Dirk de Geest, Ortwin de Graef, Dirk Delabastita, Koenraad Geldof, Rita Ghesquière, and José Lambert. 389-403. Leuven: Leuven University Press.

2002a. "Culture Planning and Cultural Resistance in the Making and Maintaining of Entities." Sun Yat-sen Journal of Humanities 14 (April): 45-52. https://www.tau.ac.il/ itamarez/works/papers/papers/Even-Zohar_2002-Culture\%20Planning\%20and\%20Cultural\%20Resistance.pdf.

2002b. "Literature as Goods, Literature as Tools." Neohelicon 29 (1): 75-83. https://www.tau.ac.i1/ itamarez/works/papers/papers/EvenZohar_2002--

Literature $\% 20$ as $\% 20$ goods, $\% 20$ literature $\% 20$ as $\% 20$ tools $\% 20 \% 5 \mathrm{BNeohelicon} \% 5 \mathrm{D}$ .pdf.

2016. Ideational Labor and the Production of Social Energy: Intellectuals, Idea Makers and Cultural Entrepreneurs. Tel Aviv: The Culture Research Lab., Tel Aviv University.

2020. "Intercultural Competition over Resources via Contests for Symbolic Capitals." Semiotica, no. 232, 235-250. doi:10.1515/sem-2019-0038.

Günay, Kadir, trans. 1979. Türk Ulusçuluğunun Temelleri [Foundations of Turkish Nationalism: The Life and Teachings of Ziya Gökalp]. By Uriel Heyd. Ankara: Kültür Bakanlığı.

—, trans. 2002. Türk Ulusçuluğunun Temelleri [Foundations of Turkish Nationalism: The Life and Teachings of Ziya Gökalp]. By Uriel Heyd. Ankara: Kültür Bakanlığı.

Gürbilek, Nurdan. 2011. The New Cultural Climate in Turkey: Living in a Shop Window. Translated by Victoria Holbrook. London: Zed.

Heyd, Uriel. 1950. Foundations of Turkish Nationalism: The Life and Teachings of Ziya Gökalp. London: Luzac and Harvill.

. 1954. Language Reform in Modern Turkey. Jerusalem: The Israel Oriental Society.

İnalcık, Halil. 1969. "Prof. Dr. Uriel Heyd.” Belleten 33 (129): 115-116.

Karadağ, Ayşe Banu. 2011. “Türk Çeviri Tarihinde 'Mütercim' Cemil Meriç: Ön Çalışma Notları." [Cemil Meriç 'the translator' in the Turkish translation history: Preliminary remarks.] In VI. Ulusal Frankofoni Kongresi: "Geçmişten Geleceğe Türkiye'de Frankofoni” 20-22 Mayls Kafkas Üniversitesi; Bildiriler [VI. National Francophony Congress: "Francophony in Turkey: From past to the future" May 20-22 Kafkas University; Proceedings], edited by M. Emin Özcan, 285-292. Ankara: Pelin Ofset. 
Kasaba, Reşat, ed. 2008. The Cambridge History of Turkey. Vol. 4, Turkey in the Modern World. Cambridge: Cambridge University Press.

Koskinen, Kaisa, and Outi Paloposki. 2019. "New Directions for Retranslation Research: Lessons Learned from the Archeology of Retranslations in the Finnish Literary System.” Cadernos de Tração 39 (1): 23-44. doi:10.5007/2175-7968.2019v39n1p23.

Landau, Jacob M. 2004. Exploring Ottoman and Turkish History. London: Hurst.

Lapidot-Firilla, Anat. 2011. “Introducing Cemil Meriç.” Journal of Levantine Studies 1 (2): 125128. https://levantine-journal.org/wp-content/uploads/woocommerce_uploads/2016/05/jls2_Intro-Meric-1.pdf.

Layish, Aharon. 1982. "Uriel Heyd's Contribution to the Study of the Legal, Religious, Cultural, and Political History of the Ottoman Empire and Modern Turkey." Bulletin 9 (1): 35-54. doi:10.1080/13530198208705334.

Lewis, Geoffrey. 1999. The Turkish Language Reform: A Catastrophic Success. Oxford: Oxford University Press.

Macura, Vladimír. 1990. "Culture as Translation." In Translation, History, and Culture, edited by Susan Bassnett and André Lefevere, 64-70. London: Pinter.

. 2010. The Mystifications of a Nation: The "Potato Bug" and Other Essays on Czech Culture. Translated and edited by Hana Píchová and Craig Cravens. Madison: University of Wisconsin Press.

Mardin, SSerif. 1974. "Super Westernization in Urban Life in the Ottoman Empire in the Last Quarter of the Nineteenth Century." In Turkey: Geographic and Social Perspectives, edited by Peter Benedict, Erol Tümertekin, and Fatma Mansur, 403-446. Leiden: E. J. Brill.

Meriç, Cemil, trans. 1980. Ziya Gökalp'in Hayatı ve Eserleri [Foundations of Turkish Nationalism: The Life and Teachings of Ziya Gökalp]. By Uriel Heyd. Istanbul: Sebil.

. (1993) 2008. Cemil Meriç: Bütün Eserleri [Complete works of Cemil Meriç]. Vol 3, Jurnal: Cilt 2; 1966-83 [Journal: Volume 2; 1966-83]. Istanbul: İletişim.

2011. "Babel." Translated by Arzu Eker Roditakis and Saliha Paker. Journal of Levantine Studies 1 (2): 129-165. https://levantine-journal.org/product/babel-by-cemilmeric-translation/.

Özmen, Ceyda. 2019. "Retranslating in a Censorial Context: H. C. Armstrong's Grey Wolf in Turkish." Chap. 3 in Perspectives on Retranslation: Ideology, Paratexts, Methods, edited by Özlem Berk Albachten and Şehnaz Tahir Gürçağlar, 45-64. New York: Routledge. 
Sayın, Ayşe Betül. 2020. "Galilean vs. Einsteinian Science of Translation: Berman's Retranslation Hypothesis Revisited." Unpublished manuscript, last modified May 15. Microsoft Word file.

Tanpınar, Ahmet Hamdi. 2013. The Time Regulation Institute. Translated by Maureen Freely and Alexander Dawe. London: Penguin.

Tekin, Arslan. 2018. “İki Farklı Tercüme.” [Two discordant translations.] Yeniçă̆, November 23.

Toury, Gideon. 2012. Descriptive Translation Studies — and Beyond. 2nd expanded ed. Amsterdam: John Benjamins. First published 1995.

Vermeer, Hans J. 1998. "Starting to Unask What Translatology Is About.” Target 10 (1): 4168. doi:10.1075/target.10.1.03ver.

Yalçın, Adem, trans. 2001. Türk Milliyetçiliğinin Kökleri [Foundations of Turkish Nationalism: The Life and Teachings of Ziya Gökalp]. By Uriel Heyd. Istanbul: P1nar. 